\title{
VENTILATION AND SEALING IN THE CURRENT ENVELOPES IN ARCHITECTURE
}

\author{
Authors: E. Sánchez (1), A. Rolando (1)
}

(1) UPM, ETSAM, Departamento de Construcción y Tecnología Arquitectónicas. Avda. Juan de Herrera, 4. 28040. Madrid, España. edurne.sanchez.salcedo@alumnos.upm.es

\section{ABSTRACT}

State of art in relation to the legislation, research and technology of envelope systems in architecture taking into account natural ventilation and sealing to the penetration of wind driven rain.

Key words: building envelope, natural ventilation, sealing, wind-driven rain.

\section{$1 \quad$ INTRODUCTION}

The article focuses on analyzing the current state of envelope's design for an optimum natural ventilation and sealing in buildings taking into account interrelatedly the legislation and the present research on the subject.

\section{STATE OF THE ART IN RELATION TO LEGISLATION}

While reviewing and analyzing the legislation related to research, shows that there is a disparity in ideas, on one hand are the legislations that regulate the ventilation, and on the other hand those dealing with sealing.

\subsection{Legislation that takes into account the ventilation}

The Technical Building Code (CTE), approved by Royal Decree 314/2006 on May 17, recognizes the importance of good ventilation and binds to establish natural ventilation systems, hybrid or mechanical in all buildings.

The Technical Building Code (CTE) in its DB-HS 3 Health. Indoor Air Quality [1], establishes minimum ventilation flow rates for the different rooms of residential buildings and the design criteria for ventilation systems, the terms of sizing of the different construction elements, as well as the technical characteristics required to products and conditions of maintenance and preservation.

In section 1.1. Overview. Scope., refers to residential buildings and not to office buildings, leaving aside the facade treatment in office buildings. In section 3.1.1. Design. General conditions of ventilation systems. Housing., in section c) establishes that "when the outdoor frames are of class 2, 3 or 4 according to standard UNE-EN 12207:2000 should be used as inlets, vents or fixed openings of the frames; when the outdoor frames are of class 0 or 1 joints can be used as openings".

Standard UNE-EN ISO 15251:2008 [2] is about the indoor environment that affects health, productivity and welfare of the occupants. This standard specifies how to establish the indoor environment parameters for building system design and the methods for long-term evaluation of the indoor environment. It also establishes the flow of ventilation and the indoor air quality required in residential and non-residential buildings to design the natural ventilation system. 
Standard UNE-CR 1752 IN [3] is about the design criteria for indoor environment. It specifies the requirements and methods of the indoor environment quality for the design, the starting, the running and the control of ventilation systems. It also defines the categories in which the indoor environment is classified and how the ventilation rate should be determined.

\subsection{Legislation that takes into account the window's sealing}

Standard UNE-EN ISO 12207:2000 [4] classifies windows and doors according to the resistance to their air permeability. The classification is based on a comparison of the air permeability of the test sample by reference to the total area and its air permeability by reference to the joint opening length. After testing, the results are shown in tables 1 and 2, where the frames are classified in Class $0,1,2,3$ or 4 depending on their air permeability. The test method is defined in the standard UNE-EN ISO 1026:2000 that measures the amount of air passing through the sample because of the pressure.

Standard UNE-EN ISO 12208:2000 [5] classifies windows and doors according to their sealing. The test method for determining the sealing limit is defined in standard UNE-EN 1027:2000. It measures the test sample ability to resist the penetration of water and gives a classification.

Standard UNE-EN ISO 12210:2000 / AC: 2010 [6] classifies doors and windows according to withstand wind load. The test procedure is defined in standard UNE-EN ISO 12211:2000 in which samples are subjected to positive and negative pressures.

Standard UNE-EN ISO 15927-3:2011 [7] specifies two procedures for analyzing wind and rain data, so as to provide an estimate amount of water that is likely to fall on a wall penetrating through the doors and windows edges or through cracks in the building facades.

\subsection{Legislation that takes into account the light envelope's sealing}

Standard UNE-EN ISO 12152:2000 [8] specifies the requirements and the classification of the air permeability of light envelope elements. The classification in based on an air permeability comparison by reference to total area and the length of fixed joint. After testing, the light envelopes are classified in class A1, A2, A3, A4 or AE depending on their air permeability. The test method is defined in standard UNE-EN ISO 12153:2000 [9].

Standard UNE-EN ISO 12154:1999 [10] defines the requirements and the classification of sealing performance of the different parts of a light envelope. The test method is shown in the standard UNE-EN ISO 12155:2000 [11]. After the test five classes are defined: R4, R5, R6, R7 and RE.

\section{$3 \quad$ STATE OF THE ART IN RELATION TO RESEARCH}

\subsection{In relation to ventilation}

In 1994, M.J. Holmes [12] published an article about double skin facades fully glazed, in which explains that the energy demand of a building can be reduced by controlling the amount of heat passing through the outer skin. This concept leads to prescriptive building regulations associated with the thermal insulation properties of the facade. He explains that one solution is to design the facade by a careful choice of glazing with ventilation inlets through the whole facade. 
There are researches on solar stack effect that say that minimize the energy waste of a modern facade and guarantee a suitable indoor environment. The researches focus on testing on ventilation rate models simulating the thermal variations that occur in natural ventilation. As a result, ventilation rates for different exterior and interior facade designs are obtained. The research shows that the natural ventilation of spaces occurs even in high winds and sunlight cases. It has also been demonstrated that the use of conditioning devices is reduced. An example is the patented Twin-Face facade systems (Fig. 1)

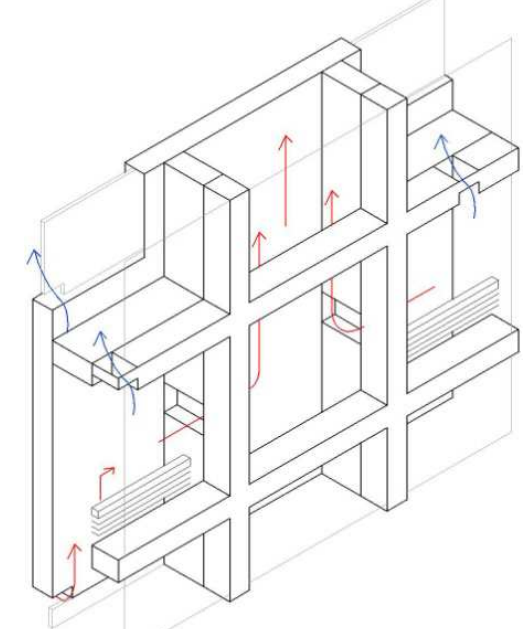

Fig. 1. Twin-Face facade functional principle

In 2011, Karava [13] presented an experimental study of airflow in buildings that employ cross- ventilation for a proper design of the natural ventilation. The research used specific areas models and tested them in a wind tunnel under wind-driven rain conditions. It was also investigated the influence of air velocity in cross-ventilated buildings. Explains that the location of the openings on a building facade in addition to the wall porosity, are parameters to be considered. Its purpose was to provide some criteria for the design and control of facade elements using cross-ventilation and natural ventilation.

\subsection{In relation to sealing}

In 2004, Bert Blocken and Jan Carmeliet [14] published a study about the state of art in relation to wind-driven rain (WDR) research in building science. WDR is rain that is given a horizontal velocity component by the wind and falls obliquely in the façade (Fig. 2). This phenomenon has destructive properties for the facade and repair and replacement will be needed and, therefore, costs increase. This problem persists because the innovative design features, building technologies and materials in present day construction don't take into account this parameter. Previously, the same authors had already presented a practical numerical method [15] in order to determine the spatial and temporal distribution of WDR in low rise buildings.

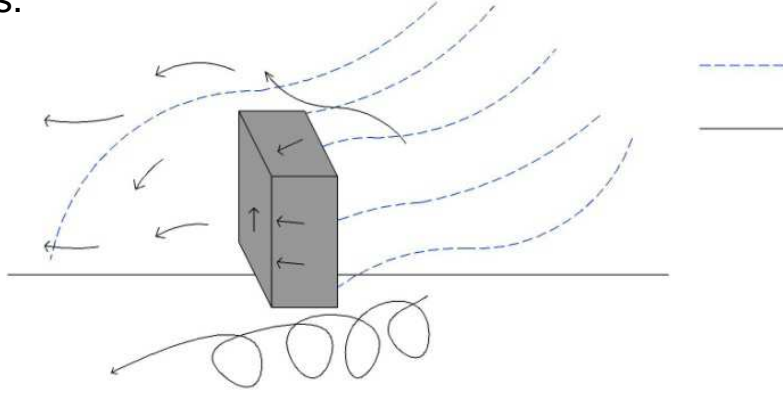

wind-driven rain trajectories wind flow

Fig. 2. Representation of the wind flow pattern and of raindrop trajectories around a building 


\section{STATE OF THE ART IN RELATION TO TECHNOLOGY}

\subsection{In relation to ventilation}

\subsubsection{Centralized ventilation}

It consists of a ventilation system concentrating the extraction at a single point of the building and, by mechanical means like extractors and fans, control the air flow. A network of ducts and suction / discharge / transfer elements, guarantee a uniform distribution.

\subsubsection{Decentralised ventilation}

Modern forms of construction make possible a high airtightness. This demands careful planning of ventilation systems [16], which can be carried out via the building envelope or by building services.

\subsubsection{Natural ventilation}

Pressure differences caused by temperature differences always result in a natural circulation of the air.

\section{Ventilation via windows}

- Exposed or concealed ventilation flaps incorporated in frames. They are grids placed horizontally or vertically in door or windows frames that allow the air change. They also minimize the air currents and can incorporate filters. They permit different adjustments so that the ventilation can be regulated.

- With an opening on one side only. The exchange of air takes place by the same opening and depends on the temperature difference between the internal and external air.

\section{By way of wind forces}

Wind flows around a building lead to forces acting on the buildings. Pressure and suction forces are the result, the magnitude and the distribution of which are influenced by the height and geometry of the building itself. On tall buildings, a double-leaf facade with appropriately designed opening elements can control the wind forces to such an extent that natural ventilation is possible via the inner leaf. Various principles can be used: Wind towers, Venturi spoilers, Cross-ventilation.

\section{By way of thermal currents}

They can be employed for extracting air for the interior. The strength of this suction effect depends on the temperature difference and the suction effect.

Three basic principles apply to the constructional implementation of this type of system:

- Double skin facade. It can make use of the thermal currents induced by the higher air temperature in the cavity to establish a ventilation concept.

- Glazed atria.

- Solar chimney. Natural ventilation is possible thanks to the physics variable known as convection. There are different facade systems that employ this principle: 
- Twin-Face facades. This patented system allows to ventilate the air spaces of high buildings, which are exposed to high wind loads, using conventional windows and reducing the waste in conditioning systems.

- Solar Chimney integrated into the facade for building ventilation (Fig. 3). An example is the Mario Muelas' and Agustín Mateo 's building in Madrid [17].

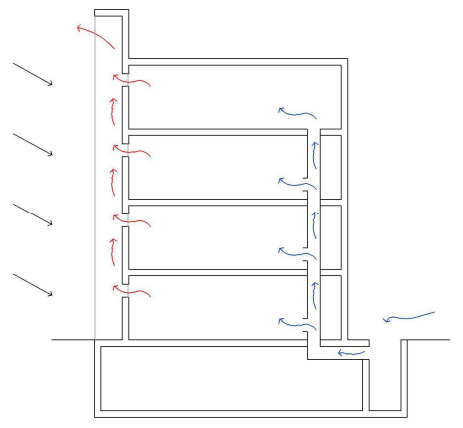

Fig. 3. Solar Chimney integrated into facade

- Natural ventilation integrated in the window jamb. This natural ventilation system is employed in the Sheffield University building by Hutton and RMJM [18] in 2009. It utilizes the stack effect to integrate an air supply and extraction system into the building envelope enabling natural ventilation. The incoming air is drawn in, through the attenuator under the window, to a vent between the outer and inner window jamb. This vent can either be allowed into the occupied room by opening the inner window or utilized to draw heat up through the chimney through the stack effect.

\section{CONCLUSIONS}

After the review and the analysis of the existing legislation related to the topic of research, it can be concluded that there are standards that take into account ventilation and sealing independently, but there is no legislation that takes into account these two issues, analyze them interrelatedly and define a design methodology for the envelopes.

There are standards that regulate ventilation and others that regulate sealing in facades. A clear example of this fact are standards UNE-EN ISO 12207:2000 and CTE DB-HS 3, discussed above. The conclusion drawn is that there is a comparison of ideas between the ventilation and the sealing criteria for the design, so that, on one hand, standard UNE-EN ISO 12207:2000 establishes that the best frames are the more watertight, and on the other hand, CTE demands to place vents to produce ventilation, while the less watertight don't need to place them.

It also must be said that the CTE DB-HS 3 establishes its scope to residential buildings, storage rooms, parking lots and garages; leaving aside the treatment in office buildings facades.

The technology used in envelopes for the ventilation of the building has evolved. First came the large solar chimneys integrated into the facade for building ventilation; then the TwinFace facades that allowed to ventilate the air spaces of high buildings; and finally a sophisticated and discreet system that utilizes the stack effect to integrate an air supply and extraction system into the frame of the building envelope enabling natural ventilation. 
Research is been done into natural ventilation in large chambers of double skin buildings. It must take into account the effect of the double skin facades configurations in reducing the air pressure on the inner frame's leaf in relation to the wind-driven rain penetration. It is also involved in reducing the energy waste and in the building thermal conditioning.

\section{STATE OF THE ART IN RELATION TO COMPUTER APPLICATIONS}

Simulation programs can be used as a tool to predict the behavior of the building envelope according to the natural ventilation and the sealing system incorporated. These tools provide the possibility of implementing iteratively multiple cases, so that we obtained results that are otherwise impossible to assess. They are also useful to facilitate the architect to make a decision to improve the ventilation conditions of the building envelope. The following simulation programs can be mentioned in relation to ventilation in buildings: COMIS, Cype Building Services, Design Builder, EnergyPlus, ESP-r, FLOVENT, I-BEAM, SMILE, SPARK and STAR-CCM+.

\section{REFERENCES}

[1] Código Técnico de la Edificación: Documento Básico HS: Salubridad. 2009.

[2] UNE-EN ISO 15251:2008. Parámetros del ambiente interior a considerar para el diseño y la evaluación de la eficiencia energética de edificios incluyendo la calidad del aire interior, condiciones térmicas, iluminación y ruido.

[3] UNE-CR 1752:2008 IN. Ventilación de edificios. Criterios de diseño para el ambiente interior.

[4] UNE-EN ISO 12207:2000. Ventanas y Puertas. Permeabilidad al aire. Clasificación.

[5] UNE-EN ISO 12208:2000. Ventanas y Puertas. Estanquidad al agua. Clasificación.

[6] UNE-EN ISO 12210:2000 / AC:2010. Ventanas y Puertas. Resistencia al viento. Clasificación.

[7] UNE-EN ISO 15927-3:2011. Comportamiento higrotérmico de edificios. Cálculo y presentación de datos climáticos. Parte 3: Cálculo de un índice de lluvia para superficies verticales a partir de datos horarios de viento y lluvia.

[8] UNE-EN ISO 12152:2002. Fachadas ligeras. Permeabilidad al aire. Requisitos de funcionamiento y clasificación.

[9] UNE-EN ISO 12153:2000. Fachadas ligeras. Permeabilidad al aire. Método de ensayo.

[10] UNE-EN ISO 12154:1999. Fachadas ligeras. Estanquidad al agua. Requisitos y Clasificación.

[11] UNE-EN ISO 12155:2000. Fachadas ligeras. Estanquidad al agua. Ensayo de laboratorio bajo presión estática.

[12] Holmes M.J. (1994). Optimization of the thermal performance of mechanically and naturally ventilated glazed facades. International Journal, vol. 5, issue 5-8, 1091-1098.

[13] Karava P. (2011). Airflow assessment in cross-ventilated buildings with operable façade elements. International Journal, vol. 46, issue 1, 266-279.

[14] Blocken B. and Carmeliet J. (2004). A review of wind-driven rain research in building science. Journal of Wind Engineering and Industrial Aerodynamics, no. 92, 1079-1130.

[15] Blocken B. and Carmeliet, J. (2002). Spatial and temporal distribution of driving rain on low-rise building. Wind and Structures, vol. 5, no.5, 441-462.

[16] Hegger, Fuchs, Stark and Zeumer. (2008). Energy Manual. Sustainable Architecture. Basel: Birkhäuser. Detail.

[17] Muelas Jiménez M. And Mateo Ortega A. (2003). Edificio residencial oeste de San Fermín. Madrid.

[18] Hutton S. Architects and RMJM. (2011). Jessop West. A+U: Architecture and Urbanism, no. $487,64-66$. 